\title{
O narodzinach Odnowy Charyzmatycznej w polskim Kościele
}

Małgorzata i Marek Nowiccy, Upili się młodym winem. Początki Odnowy w Duchu Świętym w Polsce (1975-1979), wyd. I, Warszawa 2013, ss. 416 i wyd. II popr., Warszawa 2016, ss. 540.

Jubileusze są niejednokrotnie znakomitą okazją do podsumowań. Obchodząca w 2015 roku swoją 40. rocznicę narodzin w Polsce katolicka Odnowa w Duchu Świętym doczekała się wartościowego opracowania swoich początków. Na tę rocznicę nakłada się kolejna, mianowicie „złoty jubileusz” Odnowy na świecie. 18 lutego 2017 r. upłynęło dokładnie 50 lat od słynnego ,weekendu w Duquesne", w czasie którego grupa studentów i wykładowców katolickiego Uniwersytetu Duquesne w Pittsburgu w stanie Pensylwania przeżyła doświadczenie chrztu w Duchu Świętym ${ }^{1}$. Powyższe fakty, a także niewątpliwe zamiary dokumentacyjne, doprowadziły do próby napisania pierwszej pełnej monografii początków Odnowy Charyzmatycznej, zwanej także Odnową w Duchu Świętym, w Polsce w latach 1975-1979. Podjęli się jej Małgorzata i Marek Nowiccy. Obecne we wcześniejszych pracach zarysy historii tego ruchu służyły zwykle wstępowi do jakichś innych rozważań i nie były oparte na materiale źródłowym, ewentualnie uwzględniały go w niewielkim stopniu ${ }^{2}$. Praca Nowickich tym się przede wszystkim wyróżnia, iż Autorzy zrealizowali bardzo konkretny wysiłek badawczy, gromadząc ogromną bazę źródłową w opracowaniu swojej monografii. Jak napisali we wstępie, monografia powstała jako pewnego rodzaju ,produkt uboczny” przy

${ }^{1}$ Więcej na ten temat w znanych w j. polskim publikacjach, np.: P. G. Mansfield, Jakby nowa Pięćdziesiątnica. Początek katolickiej Odnowy w Duchu Świętym, Warszawa 1993, wyd. II popr., Łódź 2017; E. O’Connor, CSC, Ruch charyzmatyczny w Kościele katolickim, Warszawa 1984; K. Ranaghan, W mocy Ducha Świętego, Warszawa 1993; F. A. Sullivan, Charyzmaty i Odnowa Charyzmatyczna, Warszawa 1986.

${ }^{2}$ Chodzi przede wszystkim o wartościową skądinąd pracę doktorską G. Poloka, W objęciach Ducha Świętego, Katowice-Bytom 2001. 
przygotowaniu serii filmów dokumentalnych na temat pierwszych przejawów obecności Odnowy Charyzmatycznej na ziemiach polskich. Widać w ich pracy warsztat naukowy profesjonalnego historyka. Podstawowe źródła należy zakwalifikować z punktu widzenia metodologii do grupy źródeł wywołanych. Są to wywiady z osobami biorącymi udział w opisywanych wydarzeniach. Najczęściej chodzi o materiał wideo ze spotkań przeprowadzonych osobiście. Rzadziej są to notatki z rozmów telefonicznych, czy wymiana listów (przesyłanych w formie klasycznej lub pocztą elektroniczną). Bazę źródłową uzupełniają archiwalia. Są to przede wszystkim wartościowe materiały gromadzone w Archiwum Głównym Ruchu Światło-Życie (dokumenty drukowane, ankiety uczestników oaz, a także materiały audio z konferencji i homilii, szczególnie założyciela popularnych oaz ks. Franciszka Blachnickiego). Niemały „wkład” w gromadzenie informacji o rodzącej się Odnowie w Duchu Świętym wniosła również Służba Bezpieczeństwa PRL-u, stąd i wykorzystanie archiwaliów z oddziałowych archiwów Instytutu Pamięci Narodowej. Charakter istotny mają dokumenty z archiwów zakonnych (krakowskich franciszkanów, sióstr Sacré Coeur, wrocławskich urszulanek Unii Rzymskiej, poznańskich dominikanów, krakowskich sióstr Córek Bożej Miłości, czy Warszawsko-Mazowieckiej Prowincji Jezuitów), z Katolickiego Uniwersytetu Lubelskiego, ICCRS (Międzynarodowych Służb Katolickiej Odnowy Charyzmatycznej w Rzymie), z Urzędu ds. Wyznań, przechowywane w warszawskim Archiwum Akt Nowych, czy wreszcie z prywatnych archiwów bohaterów opisywanych wydarzeń. Pożytecznym uzupełnieniem okazały artykuły, czy większe prace uczestników wydarzeń z lat 1975-1979, w których zawarli oni swoje refleksje lub wspomnienia o rodzącej się Odnowie. Tak szeroko zakrojona kwerenda niewątpliwie robi wrażenie. Szczególnie ze względu na fakt, iż niektórych uczestników tamtych wydarzeń nie ma już wśród żyjących, udokumentowanie ich doświadczeń znacząco podnosi rangę zgromadzonego materiału. Autorzy monografii nie dotarli do wszystkich istotnych świadków opisywanych wydarzeń, co jednakże zastrzegają we wstępie swojej książki, prosząc nawet o pomoc w uzupełnianiu dokumentacji. Ze względu na pionierski charakter opracowania literatura przedmiotu ma znaczenie niewielkie ${ }^{3}$.

Recenzowana praca podzielona została na trzy części, a te dodatkowo na rozdziały, których jest razem osiem. Konstrukcja książki, oparta o kryterium chronologiczne, jest logiczna. W ramach natomiast rozdziałów Autorzy postanowili wprowadzić jeszcze drobniejsze fragmenty, obejmujące zwykle 2-3 strony, które na pewno dynamizują odbiór lektury, choć momentami sprawiają wrażenie nadmiernego pokawałkowania narracji. Jest to, jak należy przypuszczać, spowodowane warsztatem dziennikarskim, drugą i jednocześnie na bieżąco wykonywaną

\footnotetext{
${ }^{3}$ Najważniejszą wykorzystaną monografią jest doktorat R. Derewendy, Dzieło wiary. Historia Ruchu Światło-Życie, Kraków 2010.
} 
profesją Marka Nowickiego. Cała w ogóle praca ma charakter mieszany. Z jednej strony, widać znakomicie opanowany warsztat historyka. Wyraża się on rozbudowanymi przypisami, bibliografią spisaną w pierwszym wydaniu na 14 stronach, indeksem osobowym, dobrze przygotowanym wstępem z zawartą w nim krytyką źródeł i literatury, co sprawia, że czytelnik otrzymuje do ręki pozycję o charakterze niewątpliwie naukowym. W drugim wydaniu omawianej pracy bibliografia jest znacząco powiększona, co pozwala upewnić się, że temat nie został póki co wyczerpany. Nowością jest również dodanie indeksu rzeczowego obok osobowego, obecnego już w pierwszym wydaniu monografii. Zarzucić można jedynie brak solidnego podsumowania, czego od prac naukowych można by oczekiwać. $\mathrm{Z}$ drugiej natomiast strony, kolokwializmy językowe, czy bezpośrednie zwroty do czytelników (np. s. 11, 14 w wyd. I), zdradzają zacięcie dziennikarskie. Wrażenie to pogłębia właśnie konstrukcja wewnętrzna rozdziałów pracy. Tekst przypomina krótkie komunikaty, podobne do dynamicznych w swym wyrazie „newsów” agencji prasowych. W efekcie monografia przybrała rzadką dosyć formę naukowo-dziennikarską. Można oczywiście czynić Autorom zarzut z takiego wyboru, ale nie trzeba. Jest to bowiem książka skierowana raczej do szeroko rozumianych „osób zainteresowanych”, a nie tylko naukowców-religioznawców lub historyków.

W tym miejscu warto zaznaczyć, że oba wydania różnią się nie tylko uzupełnieniami w odpowiednich partiach tekstu. Mniej jest ich w początkach pracy, natomiast zdecydowanie więcej w końcowej części, dotyczącej lat 1977-1979. Największym merytorycznie wkładem Autorów w drugą edycję tekstu jest wykorzystanie materiałów jezuity, młodego wówczas ojca Józefa Kozłowskiego. Uzupełnienia okazały się możliwe dzięki wykorzystaniu pozostawionych przez niego materiałów, przekazanych po jego śmierci do archiwum Kurii Prowincji Warszawsko-Mazowieckiej Jezuitów w Warszawie. Niewątpliwie dodatkowych cennych informacji mogłaby udzielić siostra ojca Kozłowskiego, która do dziś związana jest Odnową Charyzmatyczną i choćby z opowiadań brata zna niemało szczegółów z historii tamtych lat. Nowością jest również załączony w Postscriptum tekst ojca Sławomira Radulskiego SAC, stanowiący pogłębioną teologiczną egzegezę fragmentu Dziejów Apostolskich, dotyczącego wydarzeń z dnia Pięćdziesiątnicy. Pośród innych dodanych na koniec monografii tekstów źródłowych cennym uzupełnieniem jest raport Gary'ego Seromika z październikowej podróży do Polski w 1976 r. Odbył ją w imieniu ICO (International Communications Office), przeniesionego świeżo w sierpniu 1976 r. z Ann Arbor w USA do Brukseli, gdzie ordynariuszem był kardynał Léo Joseph Suenens, któremu papież Paweł VI powierzył odpowiedzialność za rodzącą się Odnowę Charyzmatyczną4. Odnaleziony w archiwum ICCRS dokument ukazuje pierwszy obraz rodzącego

${ }^{4}$ Szerzej o początkach Międzynarodowych Służb Katolickiej Odnowy Charyzmatycznej w tekście B. Smitha dostępnym na http://www.iccrs.org/en/about-iccrs/\#Brian_Smith. 
się otwarcia na charyzmaty wśród osób związanych z Ruchem Światło-Życie. Jest to jedyne spisane źródło tego typu, którego autorem nie jest Polak, czyli tym bardziej cenne.

Tym jednak, co w zdecydowany sposób odróżnia wydanie z roku 2013 i z 2016, jest forma książki. Otóż wydanie II ma charakter albumowy. Oznacza to, że, oprócz większego formatu książki, zmienionej szaty graficznej, kolorowych (pomarańczowych) wkładek w tekście, gdzie tłumaczono pojęcia, które mogły okazać się nieznane czytelnikowi oraz prezentowano chronologię wydarzeń, w nowej wersji monografii znalazł się jeszcze jeden istotny element. Są to fotografie poszczególnych osób lub całych grup osób, a także miejsc, związanych z początkami Odnowy w Duchu Świętym w Polsce. Jak piszą we wstępie sami Autorzy, w II wydaniu ich monografii zamieszczono ponad 350 zdjęć, które dla całego wysiłku dokumentowania pierwszych lat działań charyzmatyków w naszym kraju mają kapitalne znaczenie. Nie wszystkie pojawiające się na zdjęciach osoby udało się Autorom zidentyfikować, niemniej opublikowany materiał fotograficzny ma niewątpliwą wartość. O ile przy publikacji z 2013 r. najmocniejszą stroną monografii było zebranie ogromnej liczby źródeł wywołanych, o tyle zamieszczenie zdjęć w publikacji o trzy lata późniejszej stanowi na pewno najcenniejsze uzupełnienie wydania I.

Narracja Małgorzaty i Marka Nowickich zdradza jeszcze jeden szczegół, dotyczący ich samych. Opracowali oni dzieło o dużej wartości informacyjnej, mogące służyć wszystkim tym, którzy zainteresowali się Odnową w Duchu Świętym, ażeby poznać jej korzenie. Bardzo pomocny w tym względzie jest słownik ważniejszych pojęć ,jęzzyka" charyzmatyków (w pierwszym wydaniu znajduje się we wstępie książki, a w drugim jest rozrzucony w różnych jej częściach, zależnie od tego, gdzie dany termin się pojawia). Zabieg tego typu ułatwia niewątpliwie lekturę osobom mniej obeznanym z tematem. Jednocześnie jego zawartość ujawnia, iż Autorzy to osoby o rodowodzie oazowym. Warto zauważyć stosowanie przez nich skrótów i pojęć, przynależnych integralnie do Ruchu Światło-Życie (np. OM, COM, moderator, diakonia, ORA, OŻK, Namiot Spotkania, KKO, KODA, Tydzień Rewizji Życia), których znaczenia w słowniku już nie rozszyfrowują, jak gdyby były one wszystkim doskonale znane. Ten drobiazg wymagałby więc uzupełnienia.

Warto wskazać także na treść książki. Uwaga Autorów skupiona jest przede wszystkim na poruszeniach duchowych o charakterze charyzmatycznym, które miały miejsce w ramach Ruchu Światło-Życie. Do pewnego stopnia jest to zrozumiałe ze względu na źródła, z których korzystali (wywiady z osobami zaangażowanymi w pierwsze przejawy Odnowy Charyzmatycznej). $Z$ drugiej jednakże strony, szczególnie w ostatniej części książki, szerzej rozwijają wątki niektórych oaz, a wspominają jedynie incydentalnie osoby zaangażowane w Odnowę poza Ruchem Światło-Życie. W wyd. II poczynione zostały istotne uzupełnienia w tej 
kwestii. Najistotniejsze dotyczą aktywności o. Józefa Kozłowskiego. Zamieszczono bowiem spisane na modlitwie poruszenia wewnętrzne, z których w późniejszych latach korzystał przy okazji różnych spotkań formacyjnych. Do otrzymanych w latach 70. proroctw podchodził on w ten sposób, że, skoro nie wypełniły się w latach kształtowania się warszawskiej grupy „Maria”, to z pewnością dane były przez Ducha Świętego na lata późniejsze, gdy był duszpasterzem w Piotrkowie Trybunalskim, Toruniu, czy w Łodzi, gdzie spędził najwięcej lat. Czytelnik uzyskuje również nowe wiadomości o rozwoju Odnowy w Poznaniu, Warszawie, Krakowie, Łodzi i Białymstoku. Co ciekawe, zupełnie niknie z narracji Lublin, gdzie pierwsze poruszenia charyzmatyczne w 1976 r. zaważyły znacząco na dalszym rozwoju ruchu charyzmatycznego w polskim Kościele. Mimo wszystko jednak niewiele stosunkowo informacji znaleźć można o ówczesnej aktywności ks. Mariana Piątkowskiego, najgorliwszego wówczas ,,apostoła” Odnowy w Duchu Świętym w Polsce, jeszcze mniej o działaniach ks. Andrzeja Grefkowicza, ks. Leona Sufryda tworzącego przez całe lata legendę rekolekcji w Jutrosinie wraz z towarzyszącą mu Niną Szweycer, czy wreszcie jednej z pierwszych w Polsce osób mających za sobą doświadczenie chrztu w Duchu Świętym, ks. Franciszka Płonki. Żyjących świadków tych wydarzeń bez wątpienia można jeszcze dziś odnaleźć wśród żyjących. Podobnie zresztą ciekawie o pierwszych spotkaniach z ks. bp. Bronisławem Dembowskim opowiada amerykański jezuita Mitch Pacwa, do dziś aktywny apostolsko, co przejawia się choćby w prowadzeniu przez niego cotygodniowych programów w katolickiej telewizji EWTN.

Gdy chodzi o treść omawianej pracy, to bez wątpienia ogromny walor poznawczy mają informacje dotyczące całego wysiłku, jaki ks. Blachnicki włożył we wprowadzenie Odnowy Charyzmatycznej do Ruchu Światło-Życie. Przedstawione fakty były do tej pory praktycznie nieznane powszechnie i pomijane w redagowanych wcześniej tekstach na temat początków przejawów charyzmatycznych w Polsce. Ciekawą treść przedstawia również druga część książki, dotycząca wydarzeń roku 1976, kiedy to następuje prawdziwa eksplozja przejawów nadzwyczajnych interwencji Ducha Świętego w formie dotąd niespotykanej. Detalicznie opisywane wydarzenia obrazują coś, co wspominają młodzi wówczas ludzie uczestniczący w wakacyjnych oazach. Niejedna osoba wspominała, iż atmosfera tych dni była wręcz „nabrzmiała” od oczekiwań na to, co Duch Święty w najbliższym czasie uczyni. Radykalizm, szczególnie młodych ludzi, gdy chodzi o uczestnictwo w modlitwie, był rzeczywiście imponujący. Co najważniejsze, uczestnicy nie odchodzili ze swymi oczekiwaniami rozczarowani - rzeczywiście doświadczali Boga w sposób dotąd niespotykany. $\mathrm{Na}$ kartach omawianej książki świadectw tego typu jest bardzo wiele, a przecież nie wyczerpano ich w stu procentach. Momentami wydaje się nawet, że idąc za materiałami, które udało się zgromadzić, Autorzy gubią główny nurt narracji o historii początków Odnowy w Polsce, opisując wydarzenia ciekawe 
i poruszające, aczkolwiek niemające kluczowego znaczenia dla rozwoju tego strumienia łaski w polskim Kościele. Za przykłady niech wystarczą historie ks. Ireneusza Kopacza i śmierci jego ówczesnej dziewczyny (s. 78-79/s. 85-86 w wyd. II) albo odkrywanie powołań przez A. Wolińską, M. Ćwierza, L. Łucyk, czy M. Stawiarz (odpowiednio s. 222-224/266-268, 330-332/425-427, 337338/431-432, 338-340/434-436). Do najwartościowszych momentów części trzeciej omawianej pracy, która ma już bardziej syntetyczny charakter, zaliczyć należy informacje o reakcjach polskich hierarchów na rodzące się poruszenie (niejednoznaczne, lecz w większości wstrzemięźliwe), o reakcjach środowisk oazowych przeciwnych ,zielonoświątkowym” nowinkom, o ówczesnym bronieniu przez ks. Blachnickiego niedojrzałości, z jaką młodzi ludzie przyjmowali charyzmaty i wyrażali swe zaangażowanie (notabene szkoda, że Autorzy nie opisali, na czym owe niedojrzałe, młodzieńcze reakcje polegały), o entuzjazmie ewangelizacyjnym osób, które przeżyły chrzest w Duchu Świętym, wyrażającym się w prowadzeniu wielkopostnych rekolekcji w 1977 r. (znów brakuje informacji, jak te rekolekcje przeprowadzano), a wreszcie o rodzącej się emancypacji ludzi świeckich w ramach Kościoła, co powodowało napięcia na linii duchowni-świeccy a nieraz nawet poważne przesilenia.

$\mathrm{Z}$ tezami stawianymi przez Autorów trudno jest polemizować. Powodem jest wspomniana już na początku szeroka baza źródłowa w pionierskiej na temat początków Odnowy Charyzmatycznej w Polsce monografii. Jedynym kontrowersyjnym wątkiem narracji wydaje się koncepcja „dwóch nurtów” Odnowy w naszym kraju. Autorzy nazywają „nurtami” formy koordynacji rodzących się grup modlitewnych - tych w ramach Oazy i tych poza nią. Z treści książki wynika, że w pewnym momencie doszło nawet do sporów pomiędzy osobami, chcącymi odegrać rolę centrum koordynującego, tzn. pomiędzy ks. Franciszkiem Blachnickim i o. Adamem Schultzem SJ. Żartobliwie można by stwierdzić, że Autorom udało się uchwycić pewnego rodzaju spór o „,copyright” na koordynowanie działań Ducha Świętego w początkach polskiej Odnowy. Miał on niewątpliwie miejsce i doprowadził do wprowadzenia odmiennych formacji oraz dróg, prowadzących do otwarcia się na działanie Ducha Świętego. Natomiast podstawy teologiczne, objawianie się charyzmatów, sposoby modlitwy, entuzjazm i ,zaraźliwość" doświadczenia mocy Bożej były identyczne. Faktycznie bowiem, choć wiele jest różnic wewnętrznych w Odnowie w Duchu Świętym na świecie, a nawet na gruncie polskim, to jednak nikt nie próbuje dzielić jej na kolejne nurty, np. jezuicki (ze względu na formację), ewangelizacyjny (ze względu na formy działania zaczerpnięte ze szkół nowej ewangelizacji), czy też nurt wspólnot życia (popularny głównie we francuskiej Odnowie, ale obecny także w Polsce). Podważałbym więc metodologiczne założenie, że w początkach Odnowy Charyzmatycznej w Polsce zaistniały dwa nurty i ograniczyłbym się do stwierdzenia, że 
pojawiły się spory, które przezwyciężano, co wyraźne jest na kartach monografii, szczególnie w wydaniu drugim.

W tym też wydaniu Autorzy, podpierając swoją tezę o dwóch nurtach (s. 327-328), wybiegli w swoich refleksjach w lata 80. i 90. Piszą, że w 1988 r. „nurt” niezwiązany z Ruchem Światło-Życie zorganizował II Kongres Odnowy w Duchu Świętym w Polsce i że pokrywał się on z terminem pierwszego turnusu wakacyjnych rekolekcji oazowych, co w domyśle eliminowało uczestnictwo oazowiczów. Co więcej, w Krajowym Zespole Koordynatorów Odnowy w pierwszej połowie lat 90. przestali ostatecznie zasiadać przedstawiciele „nurtu” związanego z Ruchem Światło-Życie. Patrząc na powyższe argumenty, trudno oprzeć się wrażeniu, iż nie były one do końca precyzyjne. Otóż faktem jest, że do dziś wspólnoty charyzmatyczne, wywodzące się z oazy, nie są w większości zintegrowane z Krajowym Zespołem Koordynatorów (KZK) Odnowy w Duchu Świętym, co wszyscy akceptują . Próbują one odnaleźć różnego rodzaju formy zaangażowania w większych strukturach, w tym międzynarodowych, jak choćby ENC (Europejska Sieć Wspólnot $)^{6}$, RELaY (Pojednanie, Ewangelizacja, Przywództwo i Młodzież) ${ }^{7}$, czy ACCSE (Stowarzyszenie Koordynatorów Katolickich Szkół Ewangelizacji) ${ }^{8}$. Ale upatrywanie przyczyn takiego stanu rzeczy w przygotowaniach do II Kongresu Odnowy w Duchu Świętym chyba nie do końca odpowiada prawdzie - wszak ciężko było znaleźć wakacyjny termin Kongresu, skoro przez całe praktycznie wakacje odbywały się kolejne turnusy rekolekcji oazowych. Z drugiej strony, przejawy obecności w Krajowym Zespole Koordynatorów osób pochodzących z Ruchu Światło-Życie do dziś są żywe. Dość wspomnieć wieloletniego świeckiego koordynatora diecezji krakowskiej Witolda Płatka, czy też Małgorzatę Stułę-Topolską, która od 2000 r. była członkiem Rady KZK, a w latach 2003-2010 pełniła bardzo istotną funkcję wiceprzewodniczącej Zespołu.

W omawianej pracy można doszukać się pewnych nieścisłości lub drobnych błędów, jak np. niefortunne tłumaczenie statutów ICCRS (s. 38/35-36); używanie niezbyt szczęśliwego sformułowania „duchowość charyzmatyczna” (s. 173/208, 226/269), o której teologowie mówią, iż nie istnieje; nazywanie Seminarium Odnowy Życia w Duchu Świętym/Rekolekcji Ewangelizacyjnych Odnowy elementem formacji w grupach modlitewnych, podczas gdy jest raczej ewangelizacja (s. 263/poprawiono w wyd. II na s. 312); niezbyt precyzyjne przypisanie ważkiej roli członków grupy „Kanaan” w działaniach łódzkiego Ośrodka Odnowy w Duchu Świętym (s. 216-217/260). Pomijając jednakże wymienione powyżej drobia-

${ }^{5}$ Notabene, wśród niezintegrowanych z KZK grup modlitewnych wiele jest takich, które nie mają oazowych źródeł. Z punktu widzenia KZK istotne jest, że grupy te mają dobre relacje z proboszczami w swoich parafiach i biskupami diecezjalnymi.

${ }^{6} \mathrm{http}: / / \mathrm{e}-\mathrm{n}-\mathrm{c}$. org/en/our-communities.

${ }^{7} \mathrm{http}: / /$ www.relay-network.org/wp/.

${ }^{8} \mathrm{http}: / /$ www.nowaewangelizacja.pl/. 
zgi, uznać należy, iż Autorzy wykonali naprawdę potężną, pionierską w swym charakterze i wartościową pracę nad pokazaniem początków Odnowy Charyzmatycznej w Polsce. Zbierając wywiady z bohaterami ówczesnych wydarzeń, udało im się uchwycić i odmalować tamten klimat. Trudno oprzeć się wrażeniu, że w niektórych przypadkach książka prowadzi do ocalenia od zapomnienia osób i faktów niemal w ostatniej chwili. Na podkreślenie zasługuje coś, co powinno znaleźć się w zakończeniu książki, a mianowicie to, że „odnowowa fala” doprowadziła do wielu powołań do życia kapłańskiego i konsekrowanego. Pokazywało to, jak bardzo serio przeżywali wydarzenia $\mathrm{z}$ lat 70 . XX wieku ich uczestnicy. Nie mniej ważny jest również fakt, że pojawiło się w tym czasie bardzo liczne grono radykalnie nawróconych osób świeckich, do dziś zaangażowanych w życiu Kościoła na różnych polach jego aktywności.

Dariusz Jeziorny

Uniwersytet Łódzki Katedra Historii Powszechnej Najnowszej 